\title{
A lactic acid-fermented oat gruel increases non-haem iron absorption from a phytate- rich meal in healthy women of childbearing age
}

Bering, Stine Brandt; Suchdev, Seema; Sjøltov, Laila; Berggren, Anna; Tetens, Inge;

Bukhave, Klaus

Published in:

British Journal of Nutrition

DOI:

10.1079/BJN20051683

Publication date:

2006

Document version

Publisher's PDF, also known as Version of record

Citation for published version (APA):

Bering, S. B., Suchdev, S., Sjøltov, L., Berggren, A., Tetens, I., \& Bukhave, K. (2006). A lactic acid-fermented oat gruel increases non-haem iron absorption from a phytate-rich meal in healthy women of childbearing age. British Journal of Nutrition, 96(1), 1-6. https://doi.org/10.1079/BJN20051683 


\title{
A lactic acid-fermented oat gruel increases non-haem iron absorption from a phytate-rich meal in healthy women of childbearing age
}

\author{
Stine Bering ${ }^{1}$, Seema Suchdev ${ }^{1}$, Laila Sjøltov ${ }^{1}$, Anna Berggren ${ }^{2}$, Inge Tetens ${ }^{1}$ and Klaus Bukhave ${ }^{1 *}$ \\ ${ }^{1}$ Department of Human Nutrition, Centre for Advanced Food Studies, The Royal Veterinary and Agricultural University, \\ Rolighedsvej 30, 1958 Frederiksberg C, Denmark \\ ${ }^{2}$ Probi AB, Ideon, Gamma 1, Sölvegatan 41, 22370 Lund, Sweden
}

(Received 29 April 2005 - Revised 26 October 2005 - Accepted 23 November 2005)

\begin{abstract}
Lactic acid-fermented foods have been shown to increase Fe absorption in human subjects, possibly by lowering pH, activation of phytases, and formation of soluble complexes of Fe and organic acids. We tested the effect of an oat gruel fermented with Lactobacillus plantarum 299v on nonhaem Fe absorption from a low-Fe bioavailability meal compared with a pasteurised, fermented oat gruel and non-fermented oat gruels. In a crossover trial twenty-four healthy women with a mean age of 25 (SD 4) years were served (A) fermented gruel, (B) pasteurised fermented gruel, (C) $\mathrm{pH}$-adjusted non-fermented gruel, and (D) non-fermented gruel with added organic acids. The meals were extrinsically labelled with ${ }^{55} \mathrm{Fe}$ or ${ }^{59} \mathrm{Fe}$ and consumed on 4 consecutive days, for example, in the order ABBA or BAAB followed by CDDC or DCCD in a second period. Fe absorption was determined from isotope activities in blood samples. The fermented gruel with live L. plantarum 299v increased Fe absorption significantly $(P<0.0001)$ compared with the pasteurised and non-fermented gruels. The lactic acid concentration in the fermented gruel was $19 \%$ higher than in the pasteurised gruel, but the Fe absorption was increased by $50 \%$. In the gruel with organic acids, the lactic acid concentration was $52 \%$ lower than in the pasteurised gruel, with no difference in Fe absorption. The fermented gruel increased non-haem Fe absorption from a phytate-rich meal in young women, indicating a specific effect of live L. plantarum $299 \mathrm{v}$ and not only an effect of the organic acids.
\end{abstract}

Non-haem iron absorption: Phytate: Lactic acid fermentation: Organic acids

Fe deficiency and low Fe stores are prevalent in infants, adolescents and women of childbearing age in both Western and developing countries (Dallman et al. 1980; Hallberg et al. 1993; Milman, 1996; World Health Organization, 1997). One cause of $\mathrm{Fe}$ deficiency is the low Fe bioavailability from foods, which is partly due to inhibiting factors in the diet, such as phytic acid and phenolic compounds. Other factors enhance $\mathrm{Fe}$ absorption. These include muscle tissue, ascorbic acid and certain other organic acids (Hallberg et al. 1989; Rossander-Hultén \& Hallberg, 1996).

Phytic acid is found mainly in the fibre fraction of cereals, vegetables and fruit (Rossander-Hultén \& Hallberg, 1996). The inhibiting effect of phytic acid is due to the formation of insoluble complexes with $\mathrm{Fe}$ at intestinal $\mathrm{pH}$. A reduction in the content of phytic acid in these foods or determining a means of inhibiting the formation of Fe-bound complexes would reduce the problem of low $\mathrm{Fe}$ absorption from foods that are rich in $\mathrm{Fe}$ and which are otherwise regarded as healthy and nutritious. Phytic acid is hydrolysed by phytases found in certain plants, micro-organisms and animal tissues. Cereal phytases are considered to have a $\mathrm{pH}$ optimum in the range 4.5-6.0 (Tijskens et al. 2001). By lowering the $\mathrm{pH}$ of foods the endogenous phytases in cereals and vegetables may be activated, thereby reducing the content of phytic acid, such as in sourdough fermentation (Navert et al. 1985).
A number of single-meal studies with lactic acid-fermented vegetables and cereals have shown a significant increase in $\mathrm{Fe}$ absorption in human subjects (Derman et al. 1980; Hallberg \& Rossander, 1982; Gillooly et al. 1983). The increased absorption of Fe from fermented foods is believed to be caused by several factors. The buffer capacity of lactic acid in the $\mathrm{pH}$ range 3-5 may hinder or delay the formation of less soluble Fe complexes with reduced bioavailability, and may lead to activation of phytases present. The low-molecular weight organic acids produced during the fermentation process are believed to be able to chelate Fe, thereby making Fe unavailable for complex binding with phytate, and may also hinder precipitation of $\mathrm{Fe}$ at intestinal $\mathrm{pH}$. The potential delayed gastric emptying rate caused by the presence of organic acids (Liljeberg \& Bjorck, 1998) may increase the exposure of Fe to the proximal intestinal epithelium and thereby increase $\mathrm{Fe}$ absorption, as shown in in vitro absorption studies (Salovaara et al. 2002, 2003).

Probiotics are live micro-organisms which, when administered in adequate amounts, confer a health benefit on the host (World Health Organization, 2001). The majority of probiotics are bacterial, with the genera Lactobacillus and Bifidobacterium being the most common type of bacteria used. The health benefits attributed to probiotics include relief of conditions such as gastrointestinal infections, certain bowel 
disorders, allergy, and urogenital infections. Furthermore, they can be taken to prevent certain diseases and modulate host immunity (Goldin, 1998; World Health Organization, 2001).

A probiotic non-dairy food product based on oatmeal fermented with the defined probiotic strain Lactobacillus plantarum 299v (Probi AB, Lund, Sweden) has shown several of the health benefits attributed to probiotics (Molin, 2001). The strain originates from the human intestinal mucosa and has been shown to survive the low $\mathrm{pH}$ of the stomach, to tolerate the bile salts in the small intestine, and to colonise the intestinal mucosa, including the upper jejunum, after oral administration in a fermented oatmeal gruel (Johansson et al. 1993). In the present study, we have examined the effect of L. plantarum $299 \mathrm{v}$ and its fermentation products, lactic acid and acetic acid, on non-haem Fe absorption from a low-Fe bioavailability meal using a cross-over design. Four different oat gruels were included to test the specific effect of $L$. plantarum 299v and organic acids: a fermented oat gruel with active L. plantarum 299v, a pasteurised fermented oat gruel with the fermentation products but inactivated bacteria, a $\mathrm{pH}$-adjusted non-fermented oat gruel, and a non-fermented oat gruel with added organic acids.

\section{Subjects and methods}

\section{Subjects}

Seventy women volunteered and were screened 2-4 weeks before the study, and twenty-four women who had relatively low $\mathrm{Fe}$ stores but were non-anaemic (i.e. serum ferritin concentrations $12-40 \mu \mathrm{g} / \mathrm{l}$ and $\mathrm{Hb}$ concentrations $\geq 110 \mathrm{~g} / \mathrm{l}$ ) were selected for the study. The twenty-four women were healthy with a mean age of 25 (SD 4) years, mean weight of 62 (SD 7) kg, and a mean BMI of 21.3 (SD 1.9) kg/m². All subjects were non-smokers and none of them were pregnant or lactating or took any vitamin or mineral supplements for $\leq 2$ months before or during the study. Eighteen subjects used oral contraceptives, but none of the subjects were routinely taking any other medication. Blood donation was not allowed for $\leq 2$ months before or during the study. Each participant received oral and written information about the study before written consent was obtained. The study was approved by the Municipal Ethical Committee of Copenhagen and Frederiksberg, Denmark (file no. KF 01-219/03) and the National Institute of Radiation Hygiene, Denmark.

\section{Experimental design}

The study was a completely randomised, double-blinded cross-over trial, in which each subject was served four test meals: (A) a fermented oat gruel; (B) a pasteurised fermented oat gruel; (C) a non-fermented oat gruel ( $\mathrm{pH}$ adjusted with lactic acid); (D) a non-fermented oat gruel with added organic acids (lactic acid and acetic acid).

Fe absorption from the four test meals was determined with the dual-label extrinsic tag method (Hallberg, 1980). Using this method, Fe absorption from the four test meals was calculated by measuring Fe absorption from two test meals simultaneously in each of two periods. The two different test meals in each period were extrinsically labelled with ${ }^{55} \mathrm{Fe}$ and ${ }^{59} \mathrm{Fe}$, respectively, and served twice on four consecutive mornings to minimise potential effects of day-to-day variation, for example, in the order ABBA. All twelve serving orders were used and assigned randomly to subjects, so that all test meals were served as the first meal in a period with equal frequency. This was important to be able to validate the possible carry-over effect of the fermented oat gruel with the live colonising bacteria within a period.

The activities of both isotopes were measured in a blood sample $18 \mathrm{~d}$ after ingestion (Bukhave et al. 2001), and the second period was subsequently carried out with the remaining test meals. Residual isotope activity from the first period was subtracted from the isotope activity levels in the blood sample from the second period.

\section{Composition of test meals and serving procedure}

Probi AB (Lund, Sweden) supplied the oat gruels for the test meals. Wholegrain oatmeal (Kungsörnen AB, Järna, Sweden) and water were mixed and a blend of different enzymes was added, followed by a specific heat treatment to reduce viscosity. The oat gruel was then heated to $90^{\circ} \mathrm{C}$ for $1 \mathrm{~h}$ to inactivate the enzymes and to kill any contaminating microorganisms already present in the gruel. For the production of the fermented oat gruel (A), the heat-treated gruel was inoculated with L. plantarum 299v (DSM 9843) (Molin et al. 1991). After fermentation, product A (viable count $1.1 \times 10^{9}$ colonyforming units/g) was chilled and stored at $4{ }^{\circ} \mathrm{C}$ with a final $\mathrm{DM}$ of $23 \mathrm{~g} / 100 \mathrm{~g}$. Product $\mathrm{B}$ was produced by pasteurisation $\left(90^{\circ} \mathrm{C}, 1 \mathrm{~h}\right)$ of product A immediately after fermentation and stored at $4^{\circ} \mathrm{C}$. Oat gruels $\mathrm{C}$ and $\mathrm{D}$ were produced in a similar manner to $\mathrm{A}$, but the inoculation of bacteria was excluded. Product $\mathrm{C}$ was instead acidified with L-lactic acid to a $\mathrm{pH}$ equivalent to that in the fermented oat gruel A, after the fermentation step. The organic acids DL-lactic acid and acetic acid were added at concentrations equivalent to those expected to be produced in oat gruel A during the fermentation. As product A contained viable bacteria the exact quantity of the individual organic acids present at the time of consumption could not be precisely determined before the preparation of product $\mathrm{C}$.

For each test meal $100 \mathrm{~g}$ oat gruel (A, B, C or D) was served with a $140 \mathrm{~g}$ wholewheat roll $(60 \mathrm{~g}$ wheat flour, $20 \mathrm{~g}$ wholewheat flour, $2 \mathrm{~g}$ salt, $2 \mathrm{~g}$ yeast, $16 \mathrm{~g}$ rapeseed oil, $40 \mathrm{~g}$ ultrapure water) with $10 \mathrm{~g}$ butter and a glass of ultra-pure water $(200 \mathrm{ml})$. The oat gruels were prepared from one batch and stored at $4{ }^{\circ} \mathrm{C}$ until serving. The wholewheat rolls were prepared in one batch, stored at $-20^{\circ} \mathrm{C}$ and reheated in an oven at $200^{\circ} \mathrm{C}$ for $10 \mathrm{~min}$ before serving.

The test meals were served in the morning after $12 \mathrm{~h}$ of fasting. Intake of a maximum of 0.5 litres water was allowed overnight. Moderate or hard physical activity or the intake of any alcohol or medication was not allowed during the $12 \mathrm{~h}$ before intake of the test meals. After consuming the test meals, the subjects were not allowed to eat or drink for $2 \mathrm{~h}$ and intake of alcohol was prohibited for $24 \mathrm{~h}$. The subjects filled in a questionnaire in connection with each test meal to ensure that they adhered to all procedures, and they were instructed to eat and drink alternately and to rinse the glass containing the oat gruel thoroughly with the water to ensure complete intake of the isotope dose. A staff member ensured that everything was eaten. 
During the experimental period the subjects filled in a detailed questionnaire on their daily eating habits.

\section{Isotopes and labelling procedure}

All meals were extrinsically labelled by adding $1 \mathrm{ml}$ isotope solution $\left({ }^{55} \mathrm{FeCl}_{3}\right.$ (NEN Life Science Products, Inc., Boston, MA, USA) or ${ }^{59} \mathrm{FeCl}_{3}$ (Amersham Biosciences Corp., Piscataway, NJ, USA) in $\mathrm{HCl}(0.1 \mathrm{~mol} / \mathrm{l}))$ directly to the oat gruels $18 \mathrm{~h}$ before serving for isotope exchange. In the first period each dose contained $37 \mathrm{kBq}{ }^{55} \mathrm{FeCl}_{3}$ or ${ }^{59} \mathrm{FeCl}_{3}$ and in the second period $74 \mathrm{kBq}{ }^{55} \mathrm{FeCl}_{3}$ or ${ }^{59} \mathrm{FeCl}_{3}$.

\section{Dietary analyses}

The four oat gruels and the bread were freeze-dried, homogenised, and analysed in duplicate for total $\mathrm{Fe}, \mathrm{Ca}, \mathrm{Zn}$, phytic acid and polyphenols. The energy content was calculated with the use of a national food composition database (Danish Tables of Food Composition, DANKOST 2000, version 1.20; Herlev, Denmark). Total Fe, $\mathrm{Ca}$ and $\mathrm{Zn}$ were determined by atomic absorption spectrophotometry (Spectra-AA 200; Varian, Mulgrave, Australia) after wet-ashing in an MES 1000 Solvent Extraction System (CEM Corp., Matthews, NC, USA) with $65 \%$ (w/v) suprapure nitric acid (Merck kgaA, Darmstadt, Germany). A typical diet (Standard Reference Material 1548a; National Institute of Standards and Technology, Gaithersburg, MD, USA) was used as the reference for Fe (35.3 (SD 3.77) $\mu \mathrm{g} / \mathrm{g}$ ), Ca (1.96 (SD 0.11) $\mathrm{mg} / \mathrm{g}$ ) and $\mathrm{Zn}$ (24.6 (SD 1.79) $\mu \mathrm{g} / \mathrm{g}$ ). The analysed values were $33.38 \mu \mathrm{g} / \mathrm{g}$, $2.00 \mathrm{mg} / \mathrm{g}$, and $23.25 \mu \mathrm{g} / \mathrm{g}$, respectively for $\mathrm{Fe}, \mathrm{Ca}$ and $\mathrm{Zn}$. Phytic acid was analysed as individual inositol tri- to hexaphosphates by high-performance ion chromatography (Carlsson et al. 2001). Polyphenols were analysed as total polyphenols by the Folin-Ciocalteu method and as proanthocyanidins using the vanillin assay with sulfuric acid (Scalbert, 1992) and the results expressed as mg gallic acid and $\mathrm{mg}(+)$ catechin equivalents, respectively. The concentration of organic acids in the oat gruels was determined by capillary GC (Richardson et al. 1989).

\section{Determination of iron status}

Blood samples were drawn from the cubital vein after the subjects had rested for $10 \mathrm{~min}$ in a supine position. $\mathrm{Hb}$ analysis was carried out on venous blood $(3.5 \mathrm{ml})$ collected in tubes containing dissolved EDTA (Vacutainer system; Becton Dickinson, Franklin Lakes, NJ, USA) using a Sysmex KX-21 automated haematology analyser (Sysmex America Inc., Mundelein, IL, USA) and appropriate controls (Eight check-3WP, 22490822; Sysmex America Inc.). Intra-assay and interassay variations were $0.5 \%(n 12)$ and $0.6 \%(n$ 27 ), respectively. Serum ferritin and $\alpha_{1}$-antichymotrypsin analyses were carried out on venous blood $(5.0 \mathrm{ml})$ collected in plain tubes (Vacutainer system; Becton Dickinson). Serum ferritin was determined by a chemiluminescent immunometric assay using an Immulite 1000 analyser (Diagnostic Products Corporation, Los Angeles, CA, USA) with appropriate reference sera (WHO 3rd international standard for ferritin (80/ 578); National Institute for Biological Standards and Control, South Mimms, Herts, UK). Intra-assay and interassay variations were $2.7 \%(n$ 15) and $5.0 \%(n$ 15), respectively. $\alpha_{1}$-Antichymotrypsin was determined by an immunoturbidimetric technique using a Cobas Mira analyser (Roche Diagnostic Systems, F Hoffman-La Roche Ltd, Basel, Switzerland) and appropriate reference sera were also analysed (European Commission certified reference material 470, no. 11924; IRMM, Geel, Belgium). Intra-assay and interassay variations were $1.4 \%\left(\begin{array}{ll}n & 12\end{array}\right)$ and $3.2 \%\left(\begin{array}{ll}n & 14\end{array}\right)$, respectively.

\section{Determination of non-haem iron absorption}

Activity of ${ }^{55} \mathrm{Fe}$ and ${ }^{59} \mathrm{Fe}$ was determined from blood samples $(60 \mathrm{ml})$ collected in tubes containing heparin as anticoagulant (Vacutainer system; Becton Dickinson). Simultaneous determination of ${ }^{55} \mathrm{Fe}$ and ${ }^{59} \mathrm{Fe}$ was performed by dry-ashing followed by recrystallisation and solubilisation before counting in a Tricarb 2100TR Liquid Scintillation Analyser (Packard Instruments, Meriden, CT, USA) with automatic quench correction according to the method described previously (Bukhave et al. 2001).

\section{Statistical analyses}

Non-haem Fe absorption data were converted to logarithms before statistical analysis, and the results were reconverted to antilogarithms. All data used for statistical analyses were normally distributed, with variance homogeneity tested by plots of residuals. The non-haem Fe absorption from the different meals was compared using a linear mixed model with $\log$ (non-haem Fe absorption) as the dependent variable, meal and ferritin as independent fixed variables and subject and subject $\times$ period interaction as random effects:

Log (non-haem Fe absorption)

$$
\begin{aligned}
= & \mu\left(\text { meal }_{\mathrm{i}}\right)+\mathrm{b} \times \text { ferritin }_{\mathrm{i}}+\mathrm{A}\left(\text { subject }_{\mathrm{i}}\right)+\mathrm{B}\left(\text { subject }_{\mathrm{i}}\right. \\
& \left.\times \text { period }_{\mathrm{i}}\right)+\varepsilon_{\mathrm{i}}
\end{aligned}
$$

For studying the carry-over effect from the first meals to the consecutive meals within each period, the alternate meal was inserted as a fixed variable in the linear mixed model:

$$
\begin{aligned}
& \log (\text { non-haem Fe absorption }) \\
& \begin{aligned}
&= \mu\left(\text { meal }_{\mathrm{i}}\right)+\alpha\left({\text { alternate } \left.\text { meal }_{\mathrm{i}}\right)+\mathrm{b} \times \text { ferritin }_{\mathrm{i}}}\right. \\
& \quad+\mathrm{A}\left(\text { subject }_{\mathrm{i}}\right)+\mathrm{B}\left(\text { subject }_{\mathrm{i}} \times \text { period }_{\mathrm{i}}\right)+\varepsilon_{\mathrm{i}}
\end{aligned}
\end{aligned}
$$

Data are presented as estimates of least-squares means and differences between estimates of means with $95 \%$ CI.

The statistical analyses were performed with the SAS statistical software package, version 8.2 (SAS Institute Inc., Cary, NC, USA), and values were considered significantly different at $P<0 \cdot 05$

\section{Results}

\section{Composition of the test meals}

The composition of the test meals and the contents of organic acids in the oat gruels are given in Table 1. 
Table 1. Composition of the test meals (including a wholewheat roll with butter), $\mathrm{pH}$ and concentrations of organic acids in the oat gruels

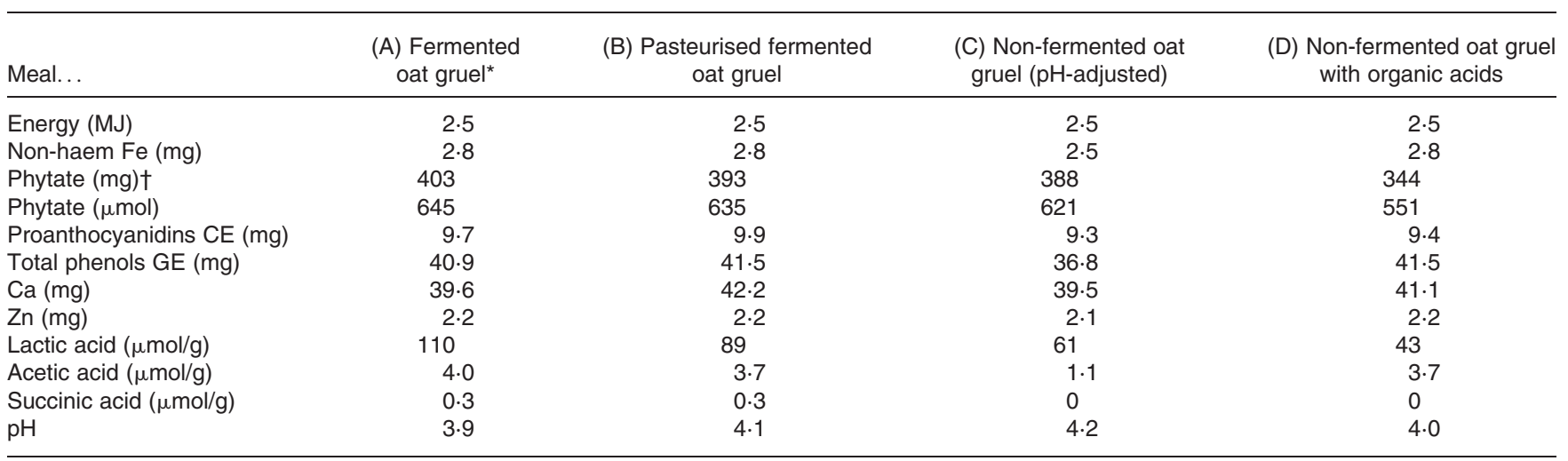

$\mathrm{CE}$, catechin equivalents; GE, gallic acid equivalents.

* Containing live Lactobacillus plantarum 299v.

†Represents individual inositol tetra- to hexaphosphates.

\section{Iron status and non-haem iron absorption}

The subjects' Hb concentrations were in the range $111-137 \mathrm{~g} / \mathrm{l}$ and serum ferritin concentrations in the range $12-40 \mu \mathrm{g} / \mathrm{l}$. As the serum ferritin concentration is sensitive to inflammation, the acute-phase protein $\alpha_{1}$-antichymotrypsin was determined in serum as a marker of an acute-phase response. The concentrations were in the region $0 \cdot 20-0 \cdot 37 \mathrm{~g} / \mathrm{l}$, indicating no acutephase response $\left(\alpha_{1}\right.$-antichymotrypsin $\left.<0.6 \mathrm{~g} / \mathrm{l}\right)$ and therefore, serum ferritin was a valid measurement of the $\mathrm{Fe}$ status in these subjects (Wieringa et al. 2002).

The non-haem Fe absorption from the four test meals calculated from the mixed linear model analysis is given in Table 2. The results show a highly significant effect of the test meal with the fermented oat gruel when comparing both absolute non-haem $\mathrm{Fe}$ absorption values and the ratios relative to the pH-adjusted non-fermented oat gruel meal $(P<0.0001)$, in which the inter-individual variations are accounted for.

The concentration of serum ferritin was significantly inversely correlated to the non-haem $\mathrm{Fe}$ absorption in the linear mixed model given in equation $1(P=0 \cdot 005)$. The linear correlation is shown in Fig. 1, with the distribution of all data points and estimated regression lines for the fermented oat gruel and the pooled data for the pasteurised fermented oat gruel and the non-fermented oat gruels, as they did not differ in Fe absorption.

The carry-over effect of each meal on the consecutive meal within a period was investigated, as L. plantarum $299 \mathrm{v}$ is known to colonise the intestine (Johansson et al. 1993) and the test meal including this bacterium may therefore have exerted an effect on the consecutive meals. The effect was investigated by inserting the alternate meal as an independent fixed variable in the linear mixed model (equation 2). Even though the overall effect of the alternate meal was far from statistical significance $(P=0 \cdot 27)$, the specific carry-over effect of the meal with the fermented oat gruel was close to reaching statistical significance $(P=0 \cdot 06)$.

\section{Discussion}

Fe absorption from the different test meals revealed a highly significant increase in non-haem $\mathrm{Fe}$ absorption from the L. plantarum $299 \mathrm{v}-f e r m e n t e d ~ o a t ~ g r u e l$, compared with the pasteurised fermented oat gruel, the non-fermented oat gruel with added organic acids, and the $\mathrm{pH}$-adjusted non-fermented oat gruel. None of the oat gruels without the active L. plantarum 299v differed in $\mathrm{Fe}$ absorption, expressed either as absolute $\mathrm{Fe}$ absorption values or as absorption ratios (Table 2). Analysis of organic acids showed that it was not possible to obtain concentrations of organic acids in the two oat gruels B and D similar to those found in A at the time of ingestion, due to the activity of L. plantarum $299 \mathrm{v}$ during storage (Table 1). The pasteurised fermented oat gruel had the smallest difference in organic acid concentration compared with the fermented oat gruel. The concentrations of lactic acid and acetic acid in the pasteurised oat gruel were 19 and

Table 2. Non-haem iron absorption from the meals containing the four different oat gruels (Mean values and $95 \%$ confidence intervals)

\begin{tabular}{|c|c|c|c|c|c|c|c|c|}
\hline Meal... & \multicolumn{2}{|c|}{$\begin{array}{l}\text { (A) Fermented } \\
\text { oat gruel }^{*}\end{array}$} & \multicolumn{2}{|c|}{$\begin{array}{c}\text { (B) Pasteurised } \\
\text { fermented oat gruel }\end{array}$} & \multicolumn{2}{|c|}{$\begin{array}{c}\text { (C) Non-fermented } \\
\text { oat gruel } \\
\text { (pH-adjusted) }\end{array}$} & \multicolumn{2}{|c|}{$\begin{array}{l}\text { (D) Non-fermented } \\
\text { oat gruel with } \\
\text { organic acids }\end{array}$} \\
\hline Non-haem Fe absorbed in blood (\%)† & $1 \cdot 1^{\mathrm{a}}$ & $0.8,1.5$ & $0.6^{\mathrm{b}}$ & $0.4,0.7$ & $0.5^{\mathrm{b}}$ & $0.4,0.7$ & $0.5^{\mathrm{b}}$ & $0.4,0.7$ \\
\hline Test meal:control meal $\ddagger$ & $2 \cdot 2^{a}$ & $1 \cdot 7,2 \cdot 9$ & $1 \cdot 1^{b}$ & $0.8,1.4$ & $1 \cdot 0^{\mathrm{b}}$ & $0.8,1.3$ & - & - \\
\hline
\end{tabular}

a,b Mean values within a row with unlike superscript letters were significantly different $(P<0.0001)$.

${ }^{*}$ Containing live Lactobacillus plantarum 299v.

† Geometric means of least-squares estimates from the mixed linear model analysis ( $n$ 24).

$\ddagger$ Geometric means of estimates of differences from the mixed linear model analysis ( $n 24)$. 
$8 \%$ lower, respectively. When comparing the Fe absorption ratios for these two meals, the ratio for the pasteurised fermented oat gruel was $50 \%$ lower. As the concentration of lactic acid in the non-fermented oat gruel meal with added organic acids was $52 \%$ lower than in the pasteurised fermented oat gruel, whereas the absorption ratio was reduced by only $9 \%$, it is unlikely that the increased $\mathrm{Fe}$ absorption found after intake of the fermented oat gruel was due mainly to an effect of the organic acids. The contents of Fe, phytate, and polyphenols in the four test meals were fairly constant. Thus the results of the present study indicate that the significant effect of the fermented oat gruel may be caused by the presence of the active lactic acid bacterium $L$. plantarum $299 \mathrm{~V}$ $\left(1.1 \times 10^{11}\right.$ colony-forming units) and not only by the presence of organic acids produced during the fermentation.

Although the subjects were selected with low Fe stores, $\mathrm{Fe}$ absorption into the blood was very low from all of the test meals $(0.4-1.5 \%)$, corresponding to a total body Fe retention of $0.5-1.9 \%$ (as $80 \%$ of the Fe absorbed enters the bloodstream (Hosain et al. 1967)), or, if calculated as absolute amounts, $0.01-0.05 \mathrm{mg}$, as the meals contained 2.5 to $2.8 \mathrm{mg} \mathrm{Fe}$. This very low absorption was presumably due to the presence of high amounts of phytate and phenolic compounds in the meals (see Table 1), and the lack of enhancers such as ascorbic acid. Enhancers were avoided in this initial study as we wished to ensure detection of even small effects
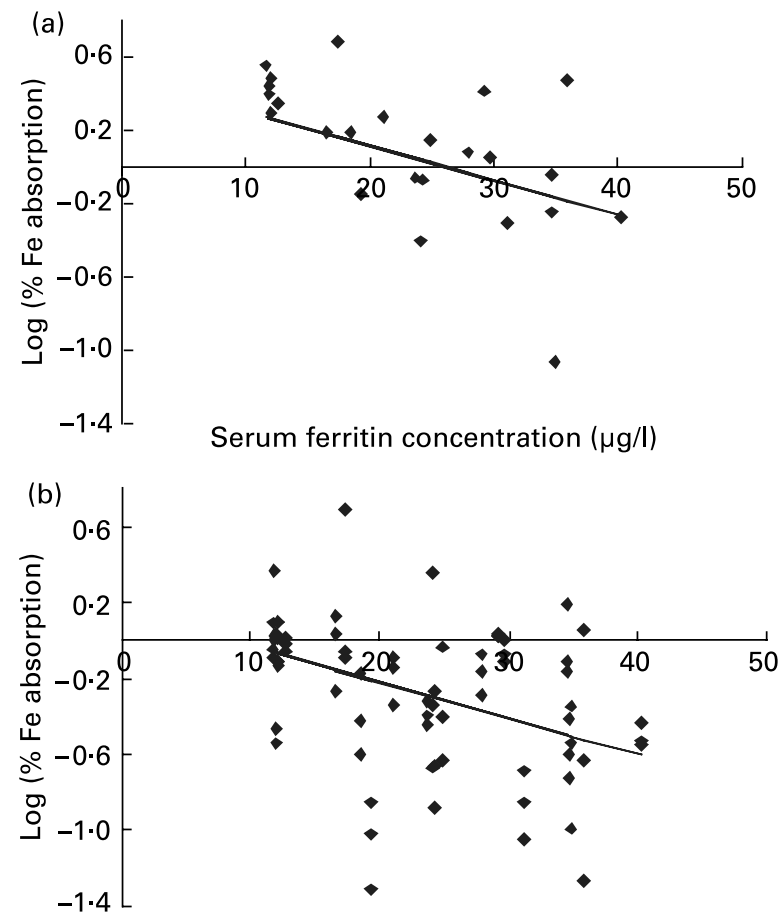

Serum ferritin concentration $(\mu \mathrm{g} / \mathrm{l})$

Fig. 1. Correlation between the percentage of non-haem $\mathrm{Fe}$ absorption (transformed to logarithms) and serum ferritin concentration. Points show the specific data for each of the twenty-four subjects and the lines describe the correlation as calculated from the mixed linear model analysis. (a) Data from meal A with the Lactobacillus plantarum 299v-fermented oat gruel, (b) pooled data from meals $B, C$, and $D$ with the pasteurised fermented oat gruel, the basic oat gruel, and the oat gruel with added organic acids. The concentration of serum ferritin was significantly inversely correlated to the non-haem Fe absorption $(P=0.005)$ of L. plantarum 299v and organic acids on Fe absorption. Previous studies on $\mathrm{Fe}$ absorption from oat porridge meals with similar contents of phytate have also shown relatively low Fe absorption values of 3.2-4.0\% (Rossander-Hulten et al. 1990; Larsson et al. 1996). In both studies, the Fe absorption was nearly double that found in the present study, but orange juice, corresponding to $70 \mathrm{mg}$ ascorbic acid, was served with the meals in those studies to achieve a realistic counteraction of the expected inhibitory effect of the phytate present in the oat products. As stated by Rossander-Hulten et al. (1990), the amount of $\mathrm{Fe}$ absorption from similar oat-containing meals without ascorbic acid would probably have been about half the amount found, i.e. 1.6-2.0\%, which corresponds well to the absorption found in the present study. However, it is questionable whether an increase of that magnitude in absorption has any significance from a practical point of view. As mentioned earlier, the present study was designed to investigate specific effects of both L. plantarum $299 \mathrm{v}$ and the organic acids, without interference from other food components. Normal meals do, however, contain more Fe, less phytate, and also enhancers such as ascorbic acid and meat. The effect of the fermented oat gruel is significant in the present study, but the improvement obtained (from 0.01 to $0.05 \mathrm{mg}$ $\mathrm{Fe}$ ) is small compared with the $12.5 \mathrm{mg}$ daily intake of Fe recommended for women in the childbearing age. Whether L. plantarum $299 \mathrm{v}$ will increase the $\mathrm{Fe}$ absorption from meals with a relatively higher basal absorption ratio remains to be established.

Fe absorption is normally described as occurring in the duodenum and proximal small intestine (Conrad \& Umbreit, 2000). Small organic acids in foods, such as lactic and acetic acid from the pasteurised fermented oat gruel and the non-fermented oat gruel are very quickly absorbed in the gastrointestinal tract. A possible explanation of the enhanced non-haem Fe absorption from the fermented oat gruel could be the colonisation of L. plantarum 299v in the mucosa of the most proximal small intestine (Johansson et al. 1993), leading to local production of lactic acid by the active bacterium, which may both decrease the local $\mathrm{pH}$ and chelate Fe in soluble complexes, both leading to an increased Fe absorption (Derman et al. 1980). This hypothesis is supported by the fact that the carry-over effect of the fermented oat gruel was close to obtaining statistical significance $(P=0 \cdot 06)$, indicating a specific effect of the colonising bacterium L. plantarum $299 \mathrm{v}$ on non-haem $\mathrm{Fe}$ absorption from the meals ingested on consecutive days. Even if the bacteria did not colonise the small intestine they may have been metabolically active and produced organic acids during intestinal transit, thereby facilitating Fe uptake.

In the previous studies describing non-haem $\mathrm{Fe}$ absorption from lactic acid-fermented meals (Derman et al. 1980; Hallberg \& Rossander, 1982; Gillooly et al. 1983), several reasons for the increased $\mathrm{Fe}$ absorption have been stated: (a) the low $\mathrm{pH}$; (b) activation of phytases present; (c) the production of organic acids. In the present study, $\mathrm{pH}$ was kept low and no correlation between $\mathrm{pH}(4 \cdot 1$ (SD 0.1)) in the test meals and Fe absorption was observed. We can therefore eliminate $\mathrm{pH}$ as the significant factor. A significant effect of endogenous phytases is also considered unlikely, as the oat gruels were heat-treated $\left(90^{\circ} \mathrm{C} ; 1 \mathrm{~h}\right)$ before the fermentation process and any phytases present in the oats were therefore inactivated. This was also verified by phytate analysis, as the amount 
detected was similar in all four test meals (mean 382 (SD 26) $\mathrm{mg}$ ), with the highest concentration actually in the fermented oat gruel. Furthermore, when considering organic acid production, results from the present study, as discussed earlier, suggest that the increase in non-haem $\mathrm{Fe}$ absorption from the fermented oat gruel meal cannot be assigned to an effect of the organic acids alone, as has been hypothesised in previous studies. In conclusion, the observed increase in $\mathrm{Fe}$ absorption in the present study seems to be attributable to a specific effect of the live L. plantarum 299v. Whether this effect is caused by colonisation of L. plantarum $299 \mathrm{v}$ in the intestine, or by production of organic acids during passage through the intestine remains to be established.

\section{Acknowledgements}

The study was funded by The Ministry of Science, Technology, and Innovation, Denmark and Vinnova, Sweden.

\section{References}

Bukhave K, Sørensen AD \& Hansen M (2001) A simplified method for determination of radioactive iron in whole-blood samples. J Trace Elem Med Biol 15, 56-58.

Carlsson NG, Bergman EL, Skoglund E, Hasselblad K \& Sandberg AS (2001) Rapid analysis of inositol phosphates. J Agric Food Chem 49, 1695-1701.

Conrad ME \& Umbreit JN (2000) Iron absorption and transport - an update. Am J Hematol 64, 287-298.

Dallman PR, Siimes MA \& Stekel A (1980) Iron deficiency in infancy and childhood. Am J Clin Nutr 33, 86-118.

Derman DP, Bothwell TH, Torrance JD, Bezwoda WR, Macphail AP, Kew MC, Sayers MH, Disler PB \& Charlton RW (1980) Iron absorption from maize (Zea mays) and sorghum (Sorghum vulgare) beer. Br J Nutr 43, 271-279.

Gillooly M, Bothwell TH, Torrance JD, Macphail AP, Derman DP, Bezwoda WR, Mills W, Charlton RW \& Mayet F (1983) The effects of organic acids, phytates and polyphenols on the absorption of iron from vegetables. Br J Nutr 49, 331-342.

Goldin BR (1998) Health benefits of probiotics. Br J Nutr 80, S203-S207.

Hallberg L (1980) Food iron absorption. In Iron, pp. 116-133 [JD Cook, editor]. New York: Churchill Livingstone.

Hallberg L, Brune M \& Rossander L (1989) Iron absorption in man: ascorbic acid and dose-dependent inhibition by phytate. Am J Clin Nutr 49, 140-144.

Hallberg L, Hulten L, Lindstedt G, Lundberg PA, Mark A, Purens J, Svanberg B \& Swolin B (1993) Prevalence of iron deficiency in Swedish adolescents. Pediatr Res 34, 680-687.

Hallberg L \& Rossander L (1982) Absorption of iron from Westerntype lunch and dinner meals. Am J Clin Nutr 35, 502-509.

Hosain F, Marsaglia G \& Finch CA (1967) Blood ferrokinetics in normal man. J Clin Invest 46, 1-9.

Johansson ML, Molin G, Jeppsson B, Nobaek S, Ahrne S \& Bengmark S (1993) Administration of different Lactobacillus strains in fermented oatmeal soup: in vivo colonization of human intestinal mucosa and effect on the indigenous flora. Appl Environ Microbiol 59, 15-20.
Larsson M, Rossander-Hulten L, Sandstrom B \& Sandberg A-S (1996) Improved zinc and iron absorption from breakfast meals containing malted oats with reduced phytate content. $\mathrm{Br} \mathrm{J} \mathrm{Nutr}$ 76, $677-688$.

Liljeberg H \& Bjorck I (1998) Delayed gastric emptying rate may explain improved glycaemia in healthy subjects to a starchy meal with added vinegar. Eur J Clin Nutr 52, 368-371.

Milman N (1996) Serum ferritin in Danes: studies of iron status from infancy to old age, during blood donation and pregnancy. Int $J$ Hematol 63, 103-135.

Molin G (2001) Probiotics in foods not containing milk or milk constituents, with special reference to Lactobacillus plantarum 299v. Am J Clin Nutr 73, 380S-385S.

Molin N, Albertsson KE, Bengmark S \& Larsson K (1991) Nutrient composition and method for the preparation thereof. US patent no. 5190 755, European patent no. 0415941, Sweden patent no. 8800822-2, Australia patent no. 620858, Norway patent no. 178321, Denmark patent no. 171057, Singapore patent no. 38358, Finland patent no. 98192, Japan patent no. 2139930 .

Navert B, Sandstrom B \& Cederblad A (1985) Reduction of the phytate content of bran by leavening in bread and its effect on zinc absorption in man. Br J Nutr 53, 47-53.

Richardson AJ, Calder AG, Stewart CS \& Smith A (1989) Simultaneous determination of volatile and non-volatile acidic fermentation products of anaerobes by capillary gas chromatography. Lett Appl Microbiol 9, 5-8.

Rossander-Hulten L, Gleerup A \& Hallberg L (1990) Inhibitory effect of oat products on non-haem iron absorption in man. Eur J Clin Nutr 44, 783-791.

Rossander-Hultén L \& Hallberg L (1996) Dietary factors influencing iron absorption - an overview. In Iron Nutrition in Health and Disease, pp. 105-115 [L Hallberg and N-G Asp, editors]. London: John Libbey \& Company Ltd.

Salovaara S, Larsson AM, Eklund-Jonsson C, Andlid T \& Sandberg AS (2003) Prolonged transit time through the stomach and small intestine improves iron dialyzability and uptake in vitro. J Agric Food Chem 51, 5131-5136.

Salovaara S, Sandberg AS \& Andlid T (2002) Organic acids influence iron uptake in the human epithelial cell line Caco-2. J Agric Food Chem 50, 6233-6238.

Scalbert A (1992) Quantitative methods for the estimation of tannins in plant tissues. In Plant Polyphenols: Synthesis, Properties, Significance, pp. 259-280 [RW Hemingway and PE Laks, editors]. New York: Plenum Press, Corp.

Tijskens LM, Greiner R, Biekman ES \& Konietzny U (2001) Modeling the effect of temperature and $\mathrm{pH}$ on activity of enzymes: the case of phytases. Biotechnol Bioeng 72, 323-330.

Wieringa FT, Dijkhuizen MA, West CE, Northrop-Clewes CA \& Muhilal (2002) Estimation of the effect of the acute phase response on indicators of micronutrient status in Indonesian infants. J Nutr 132, 3061-3066.

World Health Organization (2001) Health and Nutritional Properties of Probiotics in Food including Powder Milk with Live Lactic Acid Bacteria. Report of a Joint FAO/WHO Expert Consultation on Evaluation of Health and Nutritional Properties of Probiotics in Food Including Powder Milk with Live Lactic Acid Bacteria. Geneva: WHO/FAO.

World Health Organization (1997) Third Report on the World Nutrition Situation. Geneva: United Nations Administrative Committee on coordination sub-committee on Nutrition (ACC/SCN); available at http://www.unsystem.org/scn/archives/rwns03/index.htm/ 